\title{
Nutritional study of the Islanders on Tristan da Cunha, 1966
}

\section{2*. The energy expenditure and food intake of Tristan Islanders}

\author{
By MARGARET A. CHAMBERS AND H. E. LEWIS \\ Division of Human Physiology, National Institute for Medical Research, London $\mathrm{NW}_{3}$
}

(Received 26 fune I968-Accepted I I November 1968)

\begin{abstract}
I. Individual energy intakes and expenditures of seven Tristan men aged between 16 and 57 years, and ten Tristan women aged between 15 and 61 years, were measured daily for 7 consecutive days between May and October 1966.

2. Details of the subjects' main activities together with the energy cost of these activities are given.

3. The mean daily calorie intakes were $2650 \mathrm{kcal}$ for men and $1830 \mathrm{kcal}$ for women; the mean expenditures were 2860 and $2060 \mathrm{kcal}$ per day respectively. Separate values are given for two individuals, a brother and sister, who gave results bearing no resemblance to those of the rest of the subjects.

4. Protein, fat, carbohydrate and alcohol accounted for $12 \cdot 7,29 \cdot 6,53 \cdot 7$ and $4 \cdot 0 \%$ respectively of the men's total calorie intake and II'9, 27.2, 6r.0\% and $\circ \%$ of the women's total calorie intake. The fat content of the diet was low when compared with that of the Islanders' diet while in England, though total calorie intake was greater (Taylor, Hollingsworth \& Chambers, 1966). More than half the total calorie intake was provided by processed foodstuffs, but island produce provided a large proportion of the protein in the diet.

5. It is deduced that mean energy requirements of about $2750 \mathrm{kcal}$ per day for men and 1950 kcal per day for women are adequate for the Tristan population and that there are sufficient food supplies available to meet this requirement.
\end{abstract}

In 1963 the weekly food intake of thirty-seven Tristan families resident in Calshot, Hants, was measured shortly before they returned home. The mean intake of calories was $1750 \mathrm{kcal}$ per person per day compared with $2640 \mathrm{kcal}$ in the British population, though the composition of the diet was similar to that of present-day British diets in respect of protein, fat and carbohydrate. The Islanders were not, apparently, losing weight and it was therefore felt that they must expend less energy than the British population (Taylor et al. 1966). This was not to be further resolved in Britain because shortly afterwards they returned to Tristan da Cunha. A more searching study was indicated, particularly of energy balance on individual islanders.

In this paper we report the results of such a survey and record the Islanders' pattern of daily acivity on Tristan.

\section{EXPERIMENTAL}

\section{Island living conditions}

The Tristan Islanders live in one compact village settlement of about sixty stonebuilt thatched houses situated on a gentle slope about $30-60 \mathrm{~m}$ (100-200 ft) above sea level. The houses are single-storey cottages containing two to five rooms. Most houses are well furnished, as every family brought furniture back from England. All houses possess running water and piped sanitation. Paraffin lamps and candles are

* Paper no. I : Br. F. Nutr. (1969), 23, 227. 
used for lighting. The kitchen is generally used as a living room, though each house has a large parlour reserved for special occasions. Some houses now possess a pantry, where most of the cooking is done. Bedrooms are generally very small, though some new houses have larger rooms. Pictures and photographs decorate the walls in the main rooms and at least half the families now possess radios, record players or guitars. Some people have a reasonable supply of books, although the island library is not well patronized. Entertainment between families generally only occurs on special occasions but there is a great deal of casual visiting, especially by the women. Male Islanders can obtain employment from the administration or from the fishing company. They work an $8 \mathrm{~h}$ day with $\mathrm{I} \mathrm{h}$ for lunch and a short break in the middle of the morning and afternoon. Jobs undertaken range from fairly skilled carpentry, heavy implement driving and electrical maintenance to ordinary labouring. On fishing days long hours are worked. On these days most able-bodied men between 20 and 40 years go fishing. Older men and young boys process the crawfish catch during the evening. There were 24 fishing days between May and October 1966. The most capable girls obtain employment either as maids, pupil-teachers or in the hospital. Married women do not usually obtain employment outside the house.

The study took place during the Tristan winter and spring. General island activities during this time are thatching, mending boats, 'spading', i.e. digging potato patches, 'planting in', i.e. planting potato tubers, and thereafter weeding and spraying the growing potatoes. Table I shows the main activities throughout the year. Since the establishment of the fish freezing factory and emphasis on a cash economy, island tasks now take second place: cultivation of the potato patches and animal husbandry is generally left for evenings and weekends, though the women work in the patches during the week. Most people attend the weekly cinema shows and everyone goes to a dance. These take place about every 3 weeks and are very lively gatherings. Some of the men and boys play snooker and darts during visits to the bar or youth club.

\section{Subjects}

Seven men between 16 and 57 years and ten women between 15 and 61 years were studied, each for 7 consecutive days between May and October 1966. Details of age, haemoglobin, height and weight are given in Table 2. Choice of subjects was limited because some Islanders are not fully literate and participation in the survey required sufficient ability to make accurate recordings. However, it is felt that those who took part provide a reasonable sample of the adult population on the island, as they are from large and small, rich and poor families. Occupations of the survey subjects are shown in Table 3. One subject, Nancy, was unable to keep accurate and dependable records and her results were abandoned. Parental permission was obtained before any of the young people took part in the study. This was at first given for Joseph and then withdrawn. However, he was very keen to participate and a compromise was reached. He recorded very thoroughly all food he consumed and an estimate of quantity was made by M. A. C. His results have been analysed with those from subjects who weighed their food. The results for six men and eight women are presented in the tables and a separate description of general results provided by Frank and Catherine, 
Vol. 23

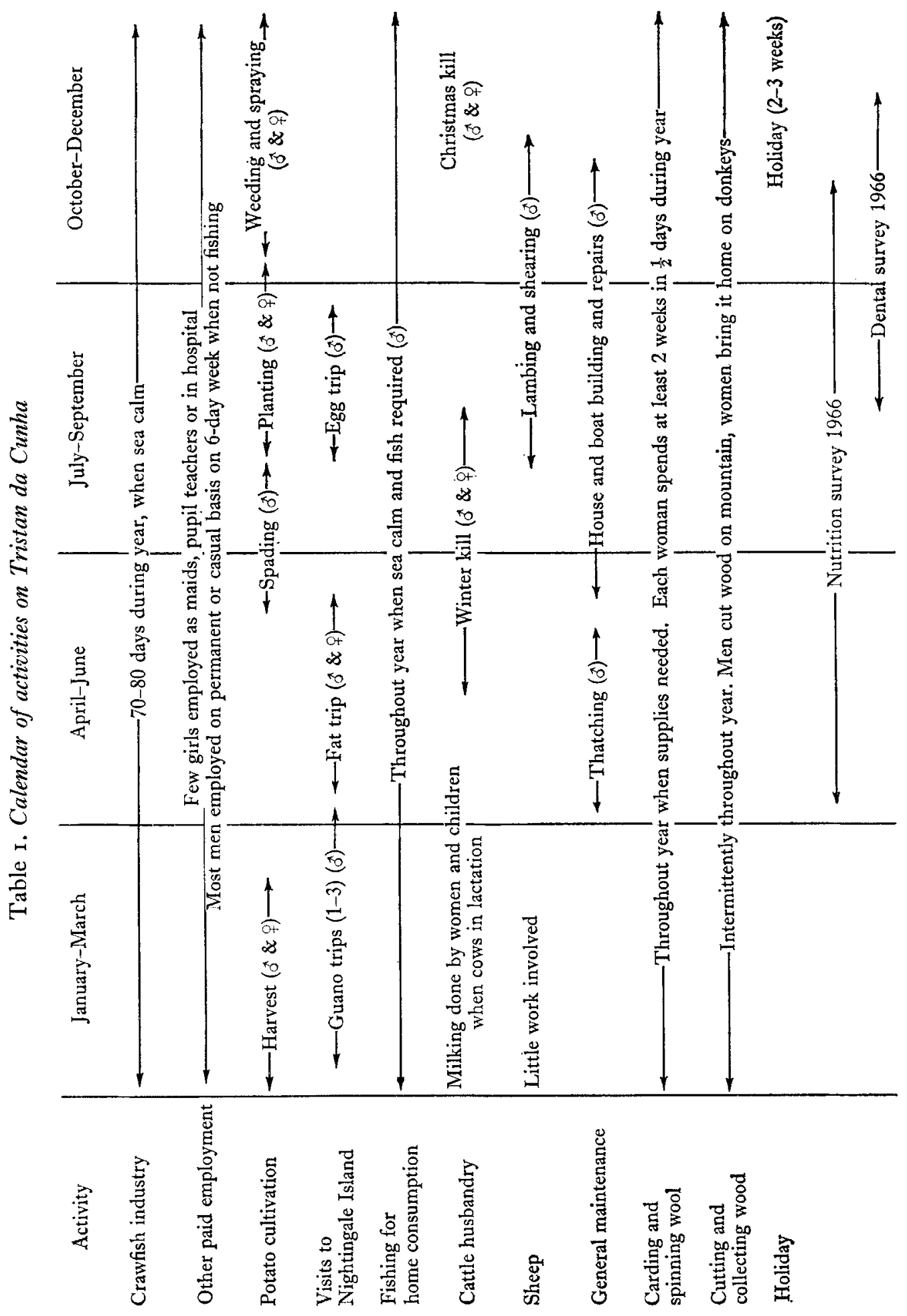


Table 2. Ages, haemoglobin levels, heights and weights of Tristan Islanders surveyed

\begin{tabular}{|c|c|c|c|c|c|c|c|c|c|}
\hline \multicolumn{5}{|c|}{ Men } & \multicolumn{5}{|c|}{ Women } \\
\hline Subject & $\begin{array}{c}\text { Age } \\
\text { (years) }\end{array}$ & $\begin{array}{l}\text { Haemo- } \\
\text { globin } \\
\text { (g/rooml } \\
\text { blood) }\end{array}$ & $\begin{array}{l}\text { Height } \\
(\mathrm{cm})\end{array}$ & $\begin{array}{c}\text { Weight } \\
(\mathrm{kg})\end{array}$ & Subject & $\begin{array}{c}\text { Age } \\
\text { (years) }\end{array}$ & $\begin{array}{l}\text { Haemo- } \\
\text { globin } \\
\text { (g/10oml } \\
\text { blood) }\end{array}$ & $\begin{array}{c}\text { Height } \\
(\mathrm{cm})\end{array}$ & $\begin{array}{c}\text { Weight } \\
(\mathrm{kg})\end{array}$ \\
\hline Stanley & 17 & $I_{3} \cdot 8$ & 172 & $64 \cdot 8$ & Doreen* & 20 & 12.9 & 159 & $40 \cdot 3$ \\
\hline Joseph & I9 & 15.0 & I 73 & $6 \mathrm{r} \cdot 5$ & Yvonnet & 16 & I3. I & 152 & 53.6 \\
\hline Barton & 33 & I 4.7 & I 85 & $78 \cdot 9$ & Stella & 24 & $12 \cdot 7$ & I 59 & 50.0 \\
\hline Thomas & 57 & I6. I & 170 & $70 \cdot 6$ & Joyt & 15 & 13.9 & $\mathrm{r} 45$ & $45 * 3$ \\
\hline Ronald* & 18 & I $2 \cdot 9$ & 160 & $49 \cdot 9$ & Gladys & 36 & 13.0 & 166 & $64 \cdot 5$ \\
\hline Bernard & 33 & 15.9 & 167 & $70 \cdot 4$ & Ann & I 5 & $12 \cdot 5$ & 155 & $49 \cdot 7$ \\
\hline Frank & 16 & $14 \% 4$ & 165 & $5 \mathrm{I} \cdot 5$ & Liza & $6 I$ & 15.0 & 159 & 50.5 \\
\hline & & & & & Mary & 32 & $14 \%$ & 159 & 53.0 \\
\hline & & & & & Catherine & 27 & 14.9 & 163 & $53 \cdot 5$ \\
\hline & & & & & Nancy & , & $14 \cdot 4$ & 157 & 50.3 \\
\hline
\end{tabular}

* $\uparrow$ In the same household.

Table 3. Occupations of survey subjects and mean daily energy intake and expenditure on Tristan in 1966

\begin{tabular}{|c|c|c|c|c|c|}
\hline Men: & \multicolumn{2}{|l|}{ Occupation } & $\begin{array}{l}\text { Intake } \\
\text { (kcal }\end{array}$ & $\begin{array}{l}\text { ture } \\
\text { (kcal) }\end{array}$ & $\begin{array}{r}\text { intake } \\
\text { (kcal) }\end{array}$ \\
\hline Stanley (June) & \multicolumn{2}{|l|}{ Mechanic, Land-Rover driver } & $33^{80}$ & 2980 & -400 \\
\hline Joseph (July) & \multicolumn{2}{|l|}{ Unemployed, island work } & 2500 & 2700 & +200 \\
\hline Barton (July) & \multicolumn{2}{|l|}{ Bulldozer driver } & 2160 & 2860 & +700 \\
\hline Thomas (September) & \multicolumn{2}{|l|}{ Carpenter } & 2930 & $3 \times 30$ & +200 \\
\hline Ronald (September) & \multicolumn{2}{|c|}{ General worker, drilling in harbour } & 2490 & 2720 & +230 \\
\hline \multirow[t]{2}{*}{ Bernard (August) } & \multicolumn{2}{|c|}{ Crane driver and general worker } & 2420 & 2780 & +360 \\
\hline & & $\begin{array}{l}\text { Mean } \\
\text { SD }\end{array}$ & $\begin{array}{r}2650 \\
435\end{array}$ & $\begin{array}{r}2860 \\
167\end{array}$ & $\begin{array}{c}200 \\
(\operatorname{SE} 150)\end{array}$ \\
\hline \multicolumn{6}{|l|}{ Women: } \\
\hline Doreen (May) & \multicolumn{2}{|l|}{ Doctor's assistant } & I 760 & I 830 & +70 \\
\hline Yvonne (May) & \multicolumn{2}{|l|}{ Pupil-teacher } & 1570 & 1940 & +370 \\
\hline Stella (July) & \multicolumn{2}{|l|}{ Housewife and maid } & 2000 & 2160 & +160 \\
\hline Joy (July) & \multicolumn{2}{|l|}{ Helping at home } & 1830 & 2140 & +310 \\
\hline Gladys (August) & \multicolumn{2}{|l|}{ Housewife and mother } & 1740 & 2130 & +570 \\
\hline Ann (August) & \multicolumn{2}{|l|}{ Schoolgirl and part-time typist } & 2320 & 2080 & -240 \\
\hline Liza (October) & \multicolumn{2}{|l|}{ Housewife } & 1570 & 1980 & +410 \\
\hline Mary (September) & \multicolumn{2}{|l|}{ Housewife and mother } & 1800 & 2030 & +230 \\
\hline \multirow[t]{3}{*}{ Nancy (September) } & Maid and hospital help & & - & - & - \\
\hline & & Mean & 1820 & 2060 & 240 \\
\hline & & SD & 245 & 150 & ( $(\mathrm{SE} 90)$ \\
\hline Frank & \multicolumn{2}{|l|}{ Store Manager } & $I 700$ & 2370 & - \\
\hline Catherine & \multicolumn{2}{|l|}{ Housewife and mother } & 1300 & 2410 & - \\
\hline
\end{tabular}

All values are given rounded to the nearest ten, though accuracy of the method warrants only results rounded to the nearest hundred.

* Date of participation in study is given in parentheses. 
brother and sister, is given, as they failed to bear resemblance to the rest of the subjects though they were both intelligent and kept their records in a conscientious manner.

\section{Measurement of energy expenditure}

Each subject kept a minute-by-minute record of his or her various activities during the week of the survey. Activities were entered on special diary cards, similar to those described by Garry, Passmore, Warnock \& Durnin (1955), which were carefully checked by M. A. C. at least once each day. At first, most subjects had difficulty in understanding these diary cards but after a few hours' help they became very keen to fill their diaries meticulously and some even admitted that they enjoyed their novel pastime. Those who did not possess a watch were provided with one for the duration of the survey period.

The energy cost of the principal activities was measured by indirect calorimetry. Sitting and standing measurements were made with a Douglas Bag and all other activities were measured with a Max Planck respirometer (Kofranyi \& Michaelis, 1940; Müller \& Franz, 1952). Most experimental periods were for Io min, though a few were of shorter duration. Only a few subjects refused to wear the respirometer. Estimates were made of the energy expended by these subjects and for any other activities not actually measured. These were based on the subjects' weight and knowledge of the manner of each activity, by use of figures presented by Durnin \& Passmore (1967). The Max Planck respirometers were calibrated at intervals throughout the survey by the method described by Durnin \& Brockway (1959). Measurement of the oxygen content of expired air was made with either the Lloyd-Haldane apparatus or the Servomex oxygen analyser. The total daily expenditure of energy was then calculated by multiplying the time spent in each activity by its calorie factor and summing the results. The energy expenditure during sleep was taken to be equivalent to the basal metabolism (Passmore \& Durnin, I955), estimated from the tables of Fleisch (I95I). That for dressing and personal necessities was taken as the energy expenditure for standing $\times \mathrm{I}^{\circ} 9$ (Passmore, Thomson \& Warnock, 1952; Garry et al. 1955 . The accuracy of this method has been discussed by Durnin \& Brockway (1959).

\section{Measurement of food intake}

Total daily food intake was measured for the individual subjects by the individual inventory method described by Garry et al. (1955) and Durnin, Blake \& Brockway (1957). The separate foods were weighed on dietetic spring balances, which the subjects were taught to use accurately before the start of each survey period. Heatresistant plastic jugs were provided for weighing liquids and plastic pots were provided for easy weighing of foods in frequent use, such as butter or margarine, sugar and jam. The weights of food and of plate wastage were entered in a log-book, which was checked at least once each day by M. A. C. Food and drink consumed away from home were recorded in the back of the subject's diary card and quantities of foods consumed were assessed. When proprietary snacks (chocolate, sweets and biscuits) were eaten, duplicate samples were purchased and weighed.

It was continually impressed on the subjects that any alterations in their eating 
habits or in their ordinary daily routine would make the study useless. The subjects respected this.

In some instances, the composition of foods was taken from standard tables, and in others peculiarly Tristan foods and dishes were analysed for moisture, protein, fat, calcium, iron and vitamin C. The results of analysis are given by Chambers \& Southgate (I969). The survey results were calculated by the nutrient evaluation computer programme designed by Pellett \& Wheeler (1965). Results of analyses of the Tristan foods were added to the programme's permanent data store. Estimates of the amino acid content of foods were made from the tables of Orr \& Watt (I957). The computed results gave the daily nutrient value of each subject's diet.
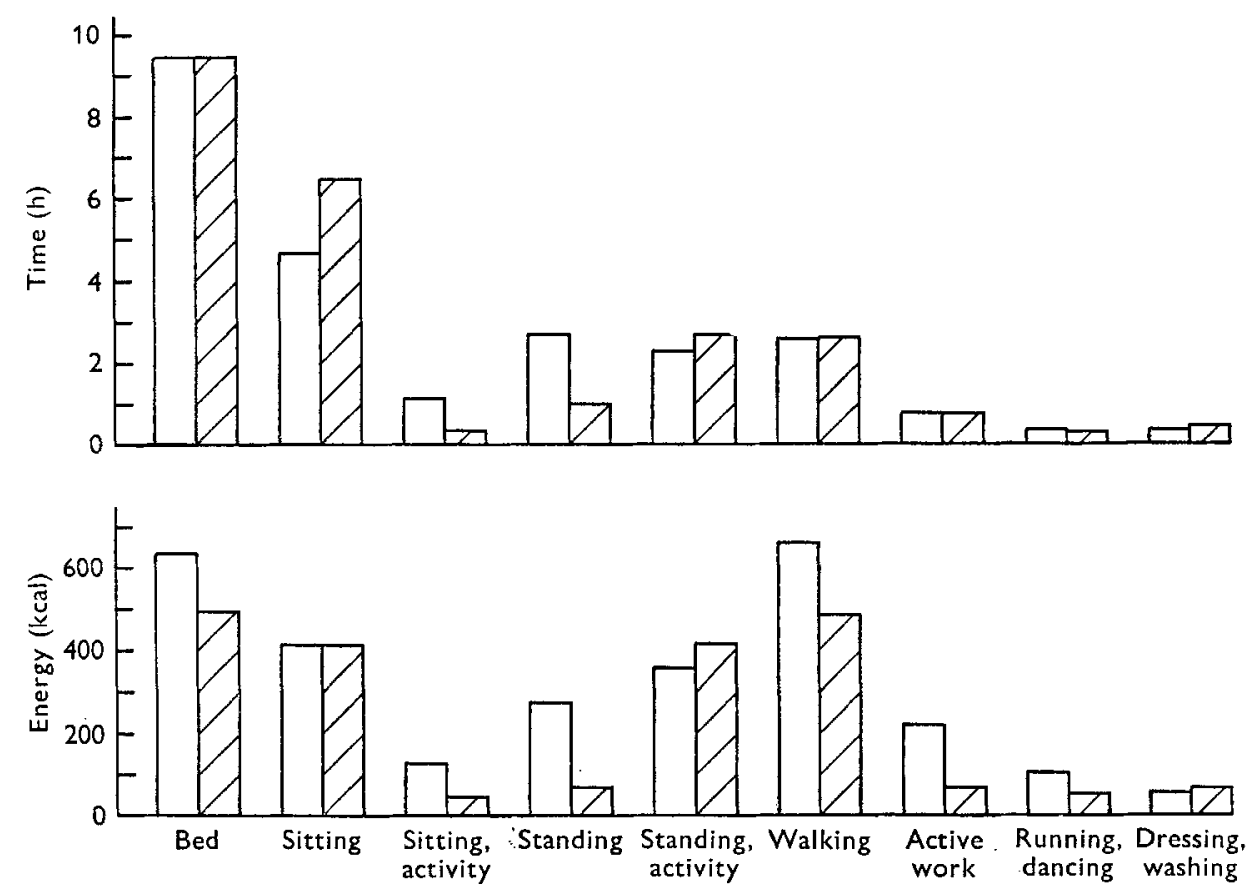

Fig. I. Time and energy expended by men and women in various activities. $\square$, Men; $\square$, women. Notes: Walking includes normal and slow walking. Sitting activity: men includes driving; women includes carding and spinning. Standing activity: men includes carpentry, fishing, labouring and playing darts; women includes cooking and housework. Active work: men includes potato cultivation, yoking steers, moving boats, processing crawfish, climbing; women includes washing, milking, potato cultivation.

\section{RESULTS}

\section{Energy expenditure}

Fig. I shows the pattern of main activities of men and women together with the equivalent energy expended. The results are similar for both groups; the same time was spent in bed and both men and women walked for more than $2.5 \mathrm{~h}$ each day. Time spent walking included periods of ambling and also walking indoors, but even allowing for these factors the Tristanians walk for longer each day than most people 
studied in Great Britain. The men spent longer standing and the women sitting. Active work or play, characterized by short bursts of high energy expenditure, amounted to little more than I $\mathrm{h}$ each day by either group.

Table 4 shows the theoretical basal metabolic rate (BMR) and the energy expenditures of each subject in the most common activities. At least two measurements on each subject were made while sitting and walking. Agreement between results was close and the mean value was used. Only one measurement was taken of standing and of any occupational activities that were measured. Between seven and ten measurements were made on each subject. Wearing a respirometer is embarrassing for any individual, and in a small community much unpleasant mirth may be directed at the wearer. In most instances the subjects were very co-operative but they understandably grew tired of the procedure towards the end of an experimental period. It was therefore only possible to measure the most important tasks. In Table 5 the results of measurements of some other activities are recorded. Comparison of these figures with those reported by Durnin \& Passmore (1967) show that the energy expended by Tristan Islanders in different tasks is similar to figures obtained elsewhere for people of comparable age, height and weight.

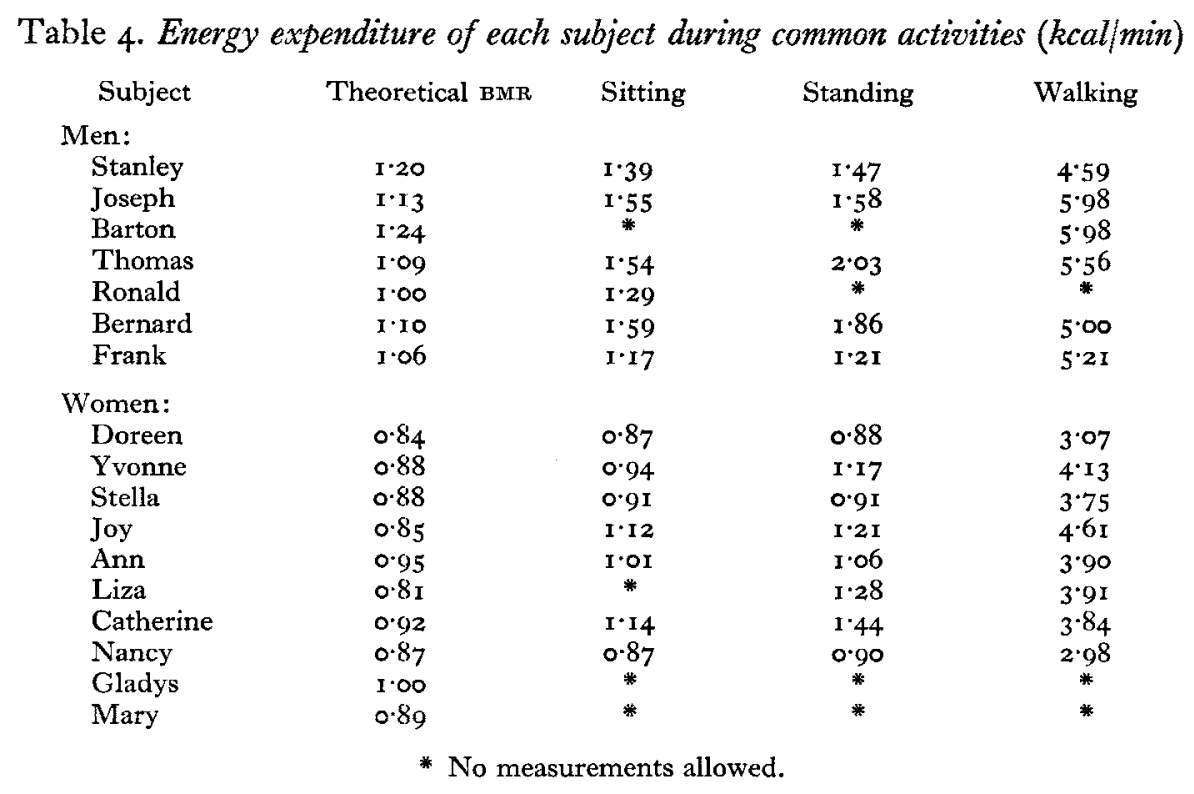

\section{Food intake}

The percentage of calories derived from protein, fat, carbohydrate and alcohol, together with the caloric equivalents, are given in Table 6. Protein accounted for a similar percentage to that normally recorded in British diets but the percentage of fat was considerably less. In Table 7 the amounts of protein, fat, calcium, iron and vitamin $\mathrm{C}$ consumed daily by men and women are shown. There was a large individual scatter but most of the intakes by the men fell within, or near, internationally recognized allowances: protein (FAO, I965), calcium (FAO I962), iron and ascorbic acid 
(British Medical Association, 1950). NDpCal\% for both groups was $8 \%$ and the amino acid score was 76 and 78 respectively for men and women with sulphur amino acids limiting. The protein quality of the diet was therefore satisfactory. Intakes of iron by the women were less than recommended allowances and intakes of vitamin $\mathrm{C}$ by both groups were low when compared with European dietaries. Potatoes provided almost the only source of vitamin $\mathrm{C}$ during the months of this study. Higher intakes of vitamin $\mathrm{C}$ would be expected during the summer from new potatoes, some vegetables and fresh fruit. No analysis for other vitamins was made but no signs of deficiency were observed, and it is felt that vitamin intakes generally were adequate.

Table 5. Mean energy expenditure of the subjects during occupational activities (kcal/min)

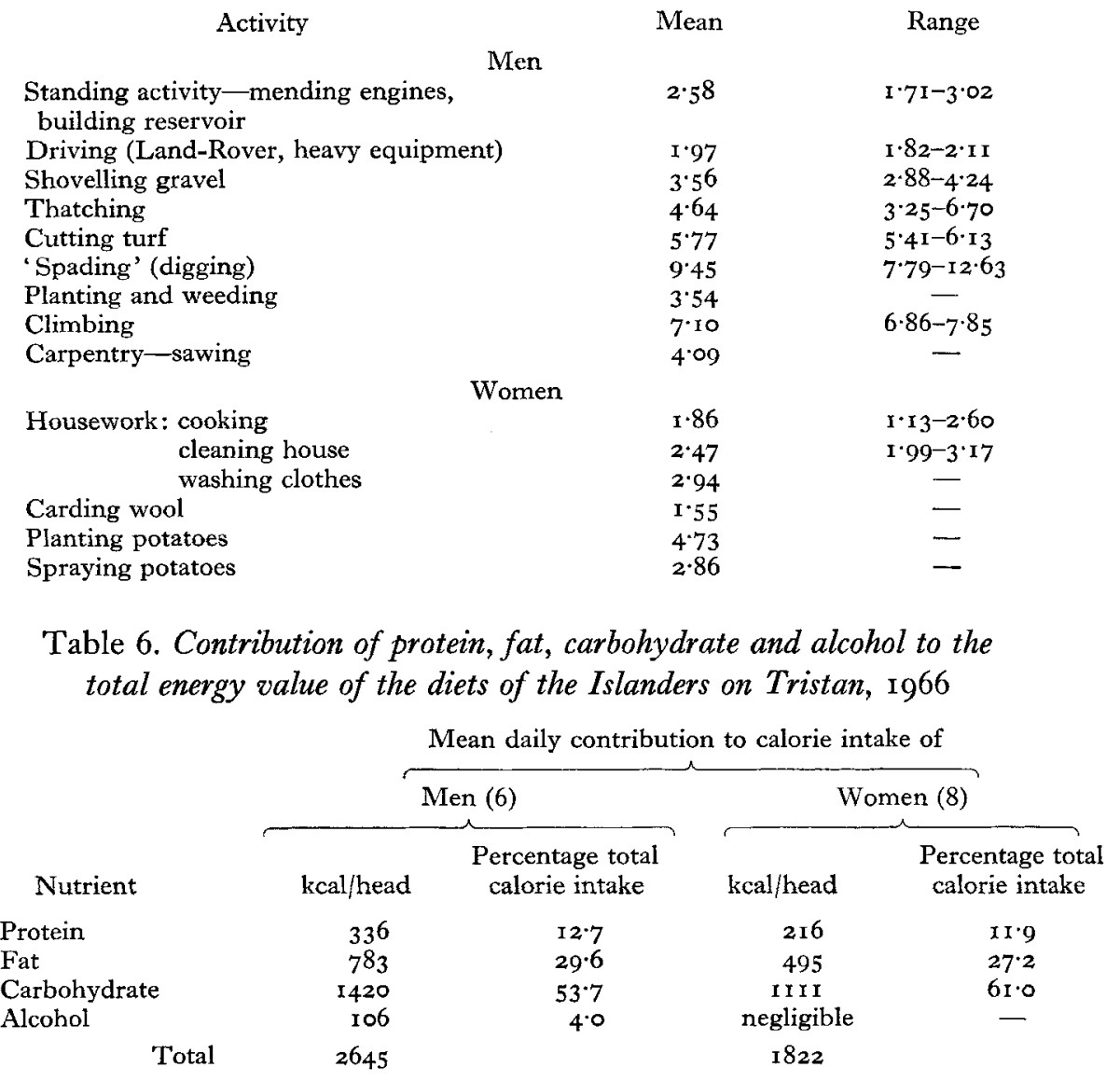

Figures in parentheses are the numbers of subjects.

Fish, eggs and meat provided almost half the protein content of the diet, about $20 \%$ of the fat and more than a third of the total iron consumed. Potatoes contributed about $10 \%$ of protein, $15 \%$ of calories and about $20 \%$ of iron to the diet of both groups. Bread, scones, cakes, puddings and biscuits were responsible for $25 \%$ of total calorie intake as also were sugar, jam, chocolates, sweets and fruit drinks. Little fat, such as 
butter or margarine, was purchased from the store and most of the fat intake was from cooked foods. Sea-bird oil or vegetable oil are used generally by the community for frying and in most pastry and cake making. About two-thirds of the total calcium intake was derived from milk and cheese.

Table 7. Mean daily intake of some nutrients (with ranges and standard deviations) of men and women on Tristan

\begin{tabular}{|c|c|c|c|c|c|c|}
\hline \multirow[b]{2}{*}{ Nutrient } & \multicolumn{3}{|c|}{ Men (6) } & \multicolumn{3}{|c|}{ Women (8) } \\
\hline & Value & SD & Range & Value & $\mathrm{SD}$ & Range \\
\hline Protein $(\mathrm{g})$ & 84 & 20 & $5^{8-108}$ & 54 & 9 & $42-66$ \\
\hline Fat $(g)$ & 87 & 27 & $62-I 32$ & 55 & 12 & $35-69$ \\
\hline Calcium (mg) & 742 & $2 \times 5$ & $537-1099$ & 519 & 120 & $378-749$ \\
\hline Iron (mg) & $14.6 \mathrm{r}$ & $2 \cdot 23$ & $12 \cdot 3 I-I 8 \cdot 64$ & $9 \cdot 89$ & $2 \cdot 62$ & $5 \cdot 71-12 \cdot 95$ \\
\hline Vitamin $\mathrm{C}(\mathrm{mg})$ & 20 & 4 & $16-24$ & I3 & 3 & $10-17$ \\
\hline
\end{tabular}

\section{Calorie balance}

The mean daily calorie intakes and expenditures by men and women and separate results for Frank and Catherine are shown in Table 3. The men recorded an $8 \%$ excess of expenditure over intake, but this is not statistically significant. For the women, this value was I I \% and is significant at the $1 \%$ level. The women's increases were less variable than those of the men, but not significantly so. It is felt that energy expenditure may have been overestimated and particularly that of time spent walking. All subjects recorded their food intake very carefully but it is easy to overlook snacks and some underestimation may have occurred. Within the limits of the method and taking into account the inexperience of the subjects in such an undertaking, these results may be said to represent a balance of calorie intake and expenditure. It was not possible to measure daily body-weights but most Islanders have been weighed at intervals since returing to Tristan da Cunha and most adults have maintained or increased their weight in this time. Haemoglobin levels were measured in 1966 and for almost all adults the results were very satisfactory. The results of investigations of height, weight and haemoglobin in the whole community will be reported in a subsequent paper.

Both Frank (aged i 6 years) and Catherine recorded very low food intakes and there was a large excess of expenditure over intake. Neither subject consumed much milk and Catherine did not take sugar in tea. Both individuals were healthy and their expenditure records show that they were active, though Frank expended less energy than the other men because of a sedentary occupation as store manager.

Frank is growing rapidly and Catherine has maintained her weight since returning to the Island, though she lost $6 \mathrm{~kg}$ in the 6 months following the birth of her child.

\section{DISCUSSION}

The results obtained were similar to values recorded in studies on less active members of the community in Great Britain, such as clerks and laboratory technicians, where energy expenditures of 2800 and $2840 \mathrm{kcal}$ per head per day were found 
(Durnin \& Passmore, 1967). Middle-aged housewives and their shop assistant daughters had only slightly higher daily energy expenditures than the Tristanian women (Durnin et al. 1957). The island results did not resemble those for Swiss peasants, where high expenditures of $3530 \mathrm{kcal}$ for men and $2890 \mathrm{kcal}$ for women were recorded (Durnin \& Passmore, 1967).

The results of this study suggest a value for calorie requirements of about $275^{\circ}$ and I950 kcal per day respectively for Tristan men and women. This is considerably higher than previous reports on the Island diet have led one to believe. The values obtained by the Norwegian expedition showed that in a good year calorie intakes would rarely exceed $2000 \mathrm{kcal}$ per day; actual values recorded in three households were 1437, I 870 and $975 \mathrm{kcal}$ per head per day (Henriksen \& Oeding, 1946).

When the Islanders were in England, the results of the family food survey confirmed this observation made 30 years previously (Taylor et al. 1966).

The men generally were employed in tasks where short bursts of activity were followed by fairly lengthy periods of idling. They were not lazy but were dependent upon the weather and conditions of the sea. Little work can be done outside during a Tristan rain-storm or in gale-force winds, and both occur frequently. The married women tended to work hard at their housework each morning and spent most afternoons visiting friends, where much knitting and tea-drinking occurred. Occasional activities such as carding parties to replenish wool supplies and work at potato patches were pleasant diversions. Those young girls employed by the administration worked fixed hours which usually only occupied the morning. Their afternoons were spent in visiting and knitting. No island home has electricity, though there are plans to install it during the next few years. In consequence, Islanders generally retire early to bed. The settlement plateau is small and the village can be crossed in 10 min and the furthest point of the plateau can be reached in about $\mathrm{I} h$ when walking. These factors all tend to restrict activity on the island.

The values provided by Frank and Catherine are difficult to assess. It is well known that, during lean periods in the Tristan history, the Islanders lived very frugally for years on end. As far as is known, no serious illness was recorded as a result of this deprivation. In contrast, they are known to gorge themselves on certain feast occasions and especially during the Christmas period. This brother and sister may have inherited the capacity to balance their calorie intake and expenditure over a long period. Fox (I953) recorded a similar occurrence in his study of the members of a village in Gambia. Frank and Catherine were weighed in May and again in October, when both were found to have gained weight, so that over this period as a whole they were in positive calorie balance.

Taylor et al. (1966) reported that while in England the Islanders consumed a diet in which the contributions of protein, fat and carbohydrate to the total calorie intake were $\mathrm{I} 2,4 \mathrm{I}$ and $47 \%$, proportions similar to present-day western diets. Fat intake fell and carbohydrate intake rose when the Islanders returned home. Imported foods provided more than half the total calorie intake but a large proportion of protein was still obtained from local produce, particularly from fish, beef and sea-birds. Consumption of alcohol by the women was negligible, but it contributed $4 \%$ of total calorie 
intake to the men's diet. This figure is similar to that found by Garry et al. (1955) in a study on miners and by Durnin, Blake, Allan, Shaw, Wilson, Blair \& Yuill (196r) with elderly steel workers. Alcohol contributed $4.9 \%$ and $3.4 \%$ respectively to the total calorie intake of these groups. These values were twice as much as for other groups studied. However, oil tanker men studied in 1967 obtained $12 \%$ of total calorie intakes from alcohol (A. Nicholson, personal communication) and in contrast alcohol consumption by the Tristanians, miners and steel workers is moderate.

Since returning home, the Islanders of Tristan da Cunha have entered upon a prosperous phase in their economy and in many respects they now lead lives similar to those of any European population. The subjects surveyed in this study were in a satisfactory state of nutritional balance as judged by measurements of food intake, energy expenditure, weight and haemoglobin.

\section{REFERENCES}

British Medical Association. (1950). Report of the Committee on Nutrition. London: British Medical Association.

Chambers, M. A. \& Southgate, D. A. T. (1969). Br. F. Nutr. 23, 227.

Durnin, J. V. G. A., Blake, E. C., Allan, M. K., Shaw, E. J., Wilson, E. A., Blair, S. \& Yuill, S. A. (196I). Br. F. Nutr. 15, 587 .

Durnin, J. V. G. A., Blake, E. C. \& Brockway, J. M. (1957). Br. F. Nutr. Ir, 85.

Durnin, J. V. G. A. \& Brockway, J. M. (1959). Br. F. Nutr. 13, 41.

Durnin, J. V. G. A. \& Passmore, R. (1967). Energy, Work and Leisure. London: Heinemann.

FAO (1962). F.A.O. Nutr. Mtg Rep. Ser, no. 30.

FAO (1965). F.A.O. Nutr. Mtg Rep. Ser. no. 37.

Fleisch, A. (1951). Helv. med. Acta I8, 23.

Fox, R. H. (1953). A study of the energy expenditure of Africans engaged in various rural activities, with special reference to some environmental physiological factors which may influence the efficiency of their work. PhD Thesis, University of London.

Garry, R. C., Passmore, R., Warnock, G. M. \& Durnin, J. V. G. A. (r955). Spec. Rep. Ser. med. Res. Coun. no. 289.

Henriksen, S. D. \& Oeding, P. (1946). In Results of the Norwegian Scientific Expedition to Tristan da Cunha 1937-1938. Vol, I, no. 5 [E. Christopherson, editor.] Oslo: Dybwad.

Kofranyi, E. \& Michaelis, H. F. (1940). Arbeitsphysiologie II, I48.

Müller, E. A. \& Franz, H. (1952). Arbeitsphysiologie 14, 499.

Orr, M. L. \& Watt, B. K. (I957). Home Econ. Res. Rep. (U.S.D.A.) no. 4.

Passmore, R. \& Durnin, J. V. G. A. (1955). Physiol. Rev. 35, 801.

Passmore, R., Thomson, J. G. \& Warnock, G. M. (1952). Br. F. Nutr. 6, 253.

Pellett, P. L. \& Wheeler, E. F. (1965). Proc. Nutr. Soc. 24, xli.

Taylor, E. C., Hollingsworth, D. F. \& Chambers, M. A. (1966). Br. Y. Nutr. 20, 393. 